Scientia Agricola

http://dx.doi.org/10.1590/0103-9016-2013-0352

\title{
Carbon sequestration and greenhouse gases emissions in soil under sewage sludge residual effects
}

\author{
Leonardo Machado Pitombo ${ }^{1,2 *}$, Janaina Braga do Carmo², Isabela Clerici de Maria ${ }^{1}$, Cristiano Alberto de Andrade ${ }^{3}$
}

\author{
${ }^{1}$ Agronomic Institute/Center for Research and Development \\ in Soil and Environmental Resources, Av. Barão de Itapura, \\ 1481 - 13012-970 - Campinas, SP - Brazil. \\ ${ }^{2}$ Federal University of São Carlos - Dept. Environmental \\ Sciences - Rod. João Leme dos Santos km $110-$ \\ 18052-780 - Sorocaba, SP - Brazil. \\ ${ }^{3}$ Embrapa Environment, Rod. SP 340 km 127.5 - \\ 13820-000 - Jaguariúna, SP - Brazil. \\ Corresponding author <Impitombo@ufscar.br> \\ Edited by: Paulo Cesar Sentelhas
}

Received October 26, 2013

Accepted August 07, 2014

\begin{abstract}
The large volume of sewage sludge (SS) generated with high carbon (C) and nutrient content suggests that its agricultural use may represent an important alternative to soil carbon sequestration and provides a potential substitute for synthetic fertilizers. However, emissions of $\mathrm{CH}_{4}$ and $\mathrm{N}_{2} \mathrm{O}$ could neutralize benefits with increases in soil $\mathrm{C}$ or saving fertilizer production because these gases have a Global Warming Potential (GWP) 25 and 298 times greater than $\mathrm{CO}_{2}$, respectively. Thus, this study aimed to determine $\mathrm{C}$ and $\mathrm{N}$ content as well as greenhouse gases (GHG) fluxes from soils historically amended with SS. Sewage sludge was applied between 2001 and 2007, and maize (Zea mays L.) was sowed in every year between 2001 and 2009. We evaluated three treatments: Control (mineral fertilizer), 1SS (recommended rate) and 2SS (double rate). Carbon stocks $(0-40 \mathrm{~cm})$ were $58.8,72.5$ and $83.1 \mathrm{Mg} \mathrm{ha}^{-1}$ in the Control, $1 \mathrm{SS}$ and 2SS, respectively, whereas $\mathrm{N}$ stocks after two years without SS treatment were $4.8,5.8$, and $6.8 \mathrm{Mg}$ ha $^{-1}$, respectively. Soil $\mathrm{CO}_{2}$ flux was highly responsive to soil temperature in SS treatments, and soil water content greatly impacted gas flux in the Control. Soil $\mathrm{N}_{2} \mathrm{O}$ flux increased under the residual effects of SS, but in 1SS, the flux was similar to that found in moist tropical forests. Soil remained as $\mathrm{a} \mathrm{CH}_{4}$ sink. Large stores of carbon following historical SS application indicate that its use could be used as a method for carbon sequestration, even under tropical conditions. Keywords: biosolid, nitrogen, carbon dioxide, methane, nitrous oxide
\end{abstract}

\section{Introduction}

The use of organic wastes for agricultural fertilization is a growing practice worldwide following the guidelines of the modern concepts of waste management, where they should be viewed as byproducts (Wilson, 2007). Especially in developing countries, sewage sludge (SS) agricultural use is being increasingly adopted as a way of managing urban wastewater treatment chains and preventing the scarcity of water and landfill sites (Beecher, 2008; Wang, 2011). From the perspective of agricultural sustainability, SS use promotes the recycling of nutrients previously removed from the soil by crops (Elser, 2012), while reducing the use of synthetic fertilizers and their detrimental environmental effects (Childers et al., 2011). Also, SS may help prevent soil erosion (Galdos et al., 2009; Garcia-Orenes et al., 2005), increase enzymatic activity in soils (Singh and Agrawal, 2008) and decrease the incidence and viability of phytopathogenic organisms detrimental to crops (Bonanomi et al., 2010).

Despite the benefits, the use of SS in agriculture could also be associated with serious environmental, agricultural, and health risks if not properly planned, managed and implemented. Among the most frequently discussed issues are the high concentrations of organic pollutants and heavy metals in SS and their potential accumulation in soils (Nogueira et al., 2010; Smith, 2009). Contamination of soils, water, and crops with human pathogens has also been an important study subject (Gerba and Smith, 2005; Navarro et al., 2009). However, while climate change is an increasing global concern, the impact of SS use in agriculture on GHG emissions such as $\mathrm{CO}_{2}, \mathrm{CH}_{4}$ and $\mathrm{N}_{2} \mathrm{O}$ has hardly been addressed.
Similar to the application of other organic fertilizers in soils, the use of SS in agriculture is prone to alter soil $\mathrm{C}$ and $\mathrm{N}$ dynamics and, consequently, change the rates of GHG emissions. For instance, part of the organic $\mathrm{C}$ present in SS might be stored more permanently in the soil and help mitigate the effects of agriculture on greenhouse emissions (Lal, 2008). On the other hand, much of the organic $\mathrm{C}$ and $\mathrm{N}$ in SS applied to soils can be used by the microbial community to fuel processes such as nitrification and denitrification, which will increase emissions of $\mathrm{N}_{2} \mathrm{O}$ (Davidson et al., 2000; Stein, 2011; Ward, 2008). Moreover, the application of SS, rich in organic matter and with high water holding capacity, may create anaerobic sites in soils and promote microbial methanogenic activity (Le Mer and Roger, 2001; Sey et al., 2008). In contrast, well-drained soils are recognized as $\mathrm{CH}_{4}$ sinks (Conrad, 2009; Holmes et al., 1999).

We hypothesized that the application of SS to supply $\mathrm{N}$ for maize cropping increases $\mathrm{N}$ and $\mathrm{C}$ content in soil, as well as the emissions of greenhouse gases such as $\mathrm{CH}_{4}, \mathrm{~N}_{2} \mathrm{O}$, and $\mathrm{CO}_{2}$. This study aimed to: (i) quantify changes in soil carbon and nitrogen stocks after successive applications of SS; (i) determine if greenhouse gas fluxes from soil increase with increases in soil organic $\mathrm{C}$ and $\mathrm{N}$ availability; and (iii) verify how soil physicalchemical parameters influence these fluxes.

\section{Materials and Methods}

\section{Site description}

The experiment was conducted in Campinas, in the state of São Paulo, located in the southeast region 
of Brazil $\left(22^{\circ} 09^{\prime} \mathrm{S}, 47^{\circ} 01^{\prime} \mathrm{W}\right)$. The soil at the site was classified as Haplic Ferralsol according to the Food and Agriculture Organization system (FAO, 1998), with clay texture (58.3\% clay, $10.3 \%$ silt, and $31.4 \%$ sand). The climate is humid-tropical with rainy summers and dry winters, and is considered to be a Cwa type, according to the Köppen classification system (Alvares et al., 2013). The mean annual temperature and rainfall are $20.5^{\circ} \mathrm{C}$ and $1,400 \mathrm{~mm}$, respectively, and $76 \%$ of the precipitation occurs between Oct and Mar (Galdos et al., 2009).

\section{Experimental design}

The area of the experimental site was divided into twelve $4 \times 25 \mathrm{~m}$ plots of uniform declivity (10\%) and separated by cemented borders and frames $(2 \mathrm{~m})$. The plots included three treatments (four replicates) on maize crops (Zea mays L.), including a control and two treatments with SS application (1SS and 2SS). In the Control, no SS was ever applied to the maize crops but synthetic fertilized $\mathrm{N}$ was added at the rate equivalent to $120 \mathrm{~kg} \mathrm{~N} \mathrm{ha}^{-1}$; the 1 SS plots were amended with the recommended amount of SS $(1 \mathrm{SS} \approx 10 \mathrm{Mg}$ $\mathrm{ha}^{-1} \mathrm{yr}^{-1}$ of SS on dry bases); while the 2SS plots were amended with twice the recommended amount $(2 \mathrm{SS} \approx$ $20 \mathrm{Mg} \mathrm{ha} \mathrm{h}^{-1} \mathrm{yr}^{-1}$ of SS on dry bases). The average contents of $\mathrm{C}$ and $\mathrm{N}$ in SS were 279 and $30 \mathrm{~kg} \mathrm{Mg}^{-1}$, respectively (Table 1 ).

Sewage sludge was applied in 1SS and 2SS for seven years (2001 to 2007), while the Control had no SS application but was fertilized with mineral N. Annual phosphorus $(\mathrm{P})$ and potassium $(\mathrm{K})$ fertilizers were also applied to the Control, and 1SS and 2SS received supplementary fertilization with $\mathrm{K}$ only. Therefore, the GHG emissions and $\mathrm{C}$ and $\mathrm{N}$ stocks presented in this study represent the effects of residual SS fertilizer application on soils. Thus, it was expected that labile material would be readily degraded and organic matter would be in a more stabilized form as verified by Fernandez et al. (2007).

Sewage sludge application - The recommended sewage sludge rate was determined according to its chemical composition (Table 1 ) and the $\mathrm{N}$ fertilization rate recommended for maize crops (Raij et al., 1997). Based on treatment adopted for wastewater treatment plant, the $\mathrm{N}$ mineralization rate used is equal to $30 \%$ in accordance with Brazilian legislation (CONAMA, 2006), which adopts the same $\mathrm{N}$ mineralization rates established by USEPA (USEPA, 1994). The SS used in the experiments was generated at the Jundiaí city water reclamation plant $\left(23^{\circ} 08^{\prime} \mathrm{S}, 47^{\circ} 00^{\prime} \mathrm{W}\right)$, in the state of São Paulo, Brazil, where the water treatment process consists of a complete-mix aerated lagoon followed by decantation. At the plant, SS was centrifuged and subjected to polyelectrolyte, physical and sanitary conditioning over 60 to 90 days by revolving in an enclosure patio (Galdos et al., 2004). Sewage sludge was manually applied to the entire treatment area and then incorporated into the soil $(0-10 \mathrm{~cm})$ using mattock, while synthetic fertilizer was applied in rows. Maize was planted annually during the summer. During the intercrop period, the soil remained uncovered.

\section{Gas and soil sampling and analysis}

On Sep 18, 2009, composite soil samples from

Table 1 - Physicochemical parameters of sewage sludges (SS) applied between the years 2001 and 2007.

\begin{tabular}{|c|c|c|c|}
\hline $\mathrm{pH}$ & Water & Volatile solids & Organic carbon \\
\hline & \multicolumn{2}{|c|}{$\longrightarrow(w / w)-$} & $\mathrm{g} \mathrm{kg}^{-1}$ \\
\hline $6.6 \pm 0.7^{a}$ & $68 \pm 3$ & $57 \pm 3$ & $279 \pm 43$ \\
\hline Kjeldahl Nitrogen & $\mathrm{NH}_{4}{ }_{4}^{+}$-Nitrogen & $\mathrm{NO}_{3}^{-}, \mathrm{NO}_{2}^{-}$-Nitrogen & $\mathrm{Fe}$ \\
\hline $\mathrm{g} \mathrm{kg}^{-1}$ & \multicolumn{2}{|c|}{$\mathrm{mg} \mathrm{kg}^{-1}$} & $\mathrm{~g} \mathrm{~kg}^{-1}$ \\
\hline $29 \pm 2$ & $371 \pm 133$ & $48 \pm 52$ & $22 \pm 3$ \\
\hline $\mathrm{P}$ & $\mathrm{Ca}$ & $\mathrm{Mg}$ & S \\
\hline \multicolumn{4}{|l|}{$\underline{-}$} \\
\hline $8.1 \pm 2.7$ & $15 \pm 11$ & $1.6 \pm 0.2$ & $20 \pm 6$ \\
\hline $\mathrm{K}$ & $\mathrm{Na}$ & Bo & $\mathrm{Zn}$ \\
\hline \multicolumn{3}{|l|}{ 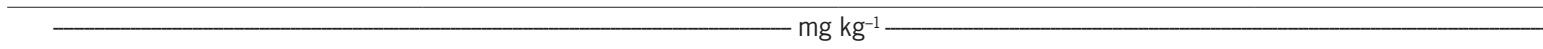 } & $1,339 \pm 279$ \\
\hline Al & As & $\mathrm{Ba}$ & $\mathrm{Cd}$ \\
\hline \multicolumn{4}{|l|}{$\mathrm{g} \mathrm{kg}^{-1}$} \\
\hline $19 \pm 2$ & $<0.5$ & $347 \pm 159 c$ & $8.3 \pm 3.6$ \\
\hline $\mathrm{Pb}$ & $\mathrm{Cu}$ & $\mathrm{Cr}$ & $\mathrm{Mn}$ \\
\hline $170 \pm 61$ & $525 \pm 267$ & $168 \pm 22$ & $606 \pm 116$ \\
\hline $\mathrm{Hg}$ & Mo & $\mathrm{Ni}$ & $\mathrm{Se}$ \\
\hline 50 & 027 & & \\
\hline$<0.5$ & $8.3 \pm 2.7$ & $59 \pm 58$ & $<0.5$ \\
\hline
\end{tabular}

$a_{ \pm}$standard deviation; bin 2004, $\mathrm{K}$ and $\mathrm{Na}$ values were $11,470 \mathrm{mg} \mathrm{kg}^{-1}$ and $8,102 \mathrm{mg} \mathrm{kg}^{-1}$, respectively; ${ }^{\mathrm{c}}$ means of 2006 and 2007 values because barium was not a parameter included in national legislation before that point. 
each plot and the same soil depth were obtained from five randomly collected subsamples. These samples were taken at depths of 0-5 cm, 5-10 cm, 10-20 cm and 20-40 cm using hand augers. Soil samples were air-dried, grounded and sieved at $150 \mu \mathrm{m}$ for total C and $\mathrm{N}$ analysis using a $\mathrm{CN}$ analyzer. For bulk density determinations, undisturbed soil samples were collected using steel cylinders $(5 \times 5 \mathrm{~cm})$ in triplicate from each plot at different depths in the trenches. $\mathrm{C}$ and $\mathrm{N}$ stocks were calculated using the following equation:

Stock $=C^{*} W s^{*} h^{*} 10,000$

where: Stock is $\mathrm{C}$ or $\mathrm{N}$ soil stock $\left(\mathrm{Mg} \mathrm{ha}^{-1}\right)$; C is the element concentration $\left(\mathrm{g} \mathrm{g}^{-1}\right) ; W s$ is the soil bulk density $\left(\mathrm{Mg} \mathrm{m}^{-3}\right) ; h$ is the soil depth $(\mathrm{m}) ;$ and 10,000 is the coefficient for converting $\mathrm{m}^{2}$ into hectare.

We determined soil $\mathrm{N}_{2} \mathrm{O}$ and $\mathrm{CH}_{4}$ fluxes using a chamber-based method (Davidson et al., 2002) in which polyvinyl chloride chambers $(30-\mathrm{cm}$ diameter) were inserted 2 -cm deep into the soil at randomly distributed points. After closing the chambers, $60 \mathrm{~mL}$ samples were collected using syringes at 1, 10,20 and $30 \mathrm{~min}$ and stored under pressure in $20 \mathrm{~mL}$ evacuated penicillin flasks sealed with gas-impermeable butylrubber septa (Bellco Glass 2048). The samples were analyzed by gas chromatography with electron capture and flame ionization detectors for $\mathrm{N}_{2} \mathrm{O}$ and $\mathrm{CH}_{4}$ respectively (Shimadzu 2014). Each gas chamber flux was calculated from slope regressions between gas concentration and collection time. Measurements of atmospheric pressure, chamber height and air temperature were taken during gas sampling to determine the air chamber volume.

Soil $\mathrm{CO}_{2}$ fluxes were determined using a dynamic chamber as proposed by Davidson et al. (2002) and adapted by Carmo et al. (2006). For these measurements, we used the same polyvinyl chloride chambers $130 \mathrm{~cm}$ in diameter) used for $\mathrm{N}_{2} \mathrm{O}$ and $\mathrm{CH}_{4}$ sampling. The chamber was coupled to a portable infrared gas analyzer that determined changes in $\mathrm{CO}_{2}$ concentration (ppmv) over time. Gas concentrations were measured in situ every $15 \mathrm{~s}$ for $5 \mathrm{~min}$, and the data were stored using the Graph-Term Datastick software installed on a palmtop connected to the equipment. Subsequently, data were transferred to another computer where the flux for each chamber was calculated using Palm Flux software, which employs a regression slope to obtain the flux measurement in $\mu \mathrm{mol} \mathrm{CO} \mathrm{Cm}^{-2} \mathrm{~s}^{-1}$.

Soil temperature was measured at a depth of 0-10 $\mathrm{cm}$ using probe thermometers to assist in the interpretation of results. All chambers were installed in the between-row position. Thus, in the Control plots the fluxes do not represent direct emissions from fertilizer because it was applied parallel to the planting line. Gas samples were collected over 20 days between Oct 14, 2009 and Sep 29. 2010. Precipitation and daily mean temperatures are shown in Figure 1.

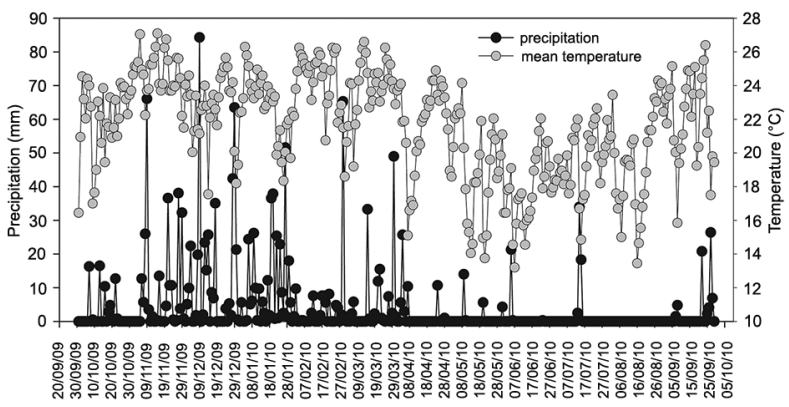

Figure 1 - Climate variables during the gas sampling period.

Gas emissions were estimated by weighting the data with seasonal fluxes (dry or wet period) to isolate conditions that support denitrification (water availability) and $\mathrm{CO}_{2}$ soil flux (temperature and water availability), because at the study site, lower temperatures coincide with lesser precipitation. The emissions representing the wet season were calculated based on the fluxes observed from Oct 1, 2009 to 31 Mar 31, 2010 (182 days). The emissions representing the dry season were calculated based on the fluxes from Apr to Sep (183 days). These periods are the same as the historically wetter and drier periods at the experimental site, respectively, according to the reported by Galdos et al. (2009). Seasonal $\mathrm{CO}_{2}$, $\mathrm{N}_{2} \mathrm{O}$ and $\mathrm{CH}_{4}$ mean fluxes for these periods were estimated, as well as weighting the emissions to allow for seasonal fluxes (Table 3).

After collecting the gases, soil samples were taken from inside the chambers to determine $\mathrm{N}$ mineral concentration and soil moisture. Soil moisture was determined by gravimetry, and mineral $\mathrm{N}$ content was determined by colorimetry of soil extracts $(2 \mathrm{M} \mathrm{KCl})$ using flow injection analysis based on the methods proposed by Kamphake et al. (1967) for $\mathrm{NO}_{3}^{-}$and by Krom (1980) for $\mathrm{NH}_{4}{ }^{+}$. Soil water-filled pore space (WFPS) was calculated as follows:

$W F P S=\operatorname{Vol} /(1-W s / S s)$

where: WFPS is the water-filled pore space $(\%)$; Vol is the volumetric water content $(\%) ; W s$ is the soil bulk density $\left(\mathrm{Mg} \mathrm{m}^{-3}\right)$; and $\mathrm{S}_{\mathrm{s}}\left(2.65 \mathrm{Mg} \mathrm{m}^{-3}\right)$ is the particle density commonly used for tropical soils (ISO, 1998).

\section{Statistical analysis}

Differences in soil characteristics and in gas fluxes among treatments were determined using analysis of variance (ANOVA), where the historical SS rate, or amount of SS applied, was considered to be the variable factor (randomized set). The mean values for each treatment were compared using Tukey test $(p<0.05$ for chemical parameters; $p<0.10$ for soil density). To assist with the interpretation of gas fluxes, we used simple and multiple regressions in which $y$ represented gas flux and $x$ represented either temperature, or WFPS or both ac- 
cording to the following equation:

$x=\left(T_{\text {soil }} / T_{\text {range }}\right)+\left(\right.$ WFPS $\left./ W F P D_{\text {range }}\right)(3)$

where: $\mathrm{T}_{\text {soil }}$ is the verified temperature at the respective point; $\mathrm{T}_{\text {range }}$ is the temperature range observed for the respective treatment; WFPS is the WFPS verified at the respective point; and WFPS range $_{\text {is }}$ the WFPS range observed for the respective treatment.

\section{Results and Discussion}

\section{Soil carbon and nitrogen}

In 1 SS, soil C contents were $79 \%, 56 \%$ and $7 \%$ higher than in the Control series at 0-5, 5-10 and 10-20 cm layers, respectively; whereas in 2SS, soil C contents were $163 \%, 121 \%$ and $22 \%$ higher than in the same layers of the Control. In samples collected at a depth below $20 \mathrm{~cm}$, there was no effect of SS on soil C content. According to soil $\mathrm{C}$ content data, the amount of SS ap-

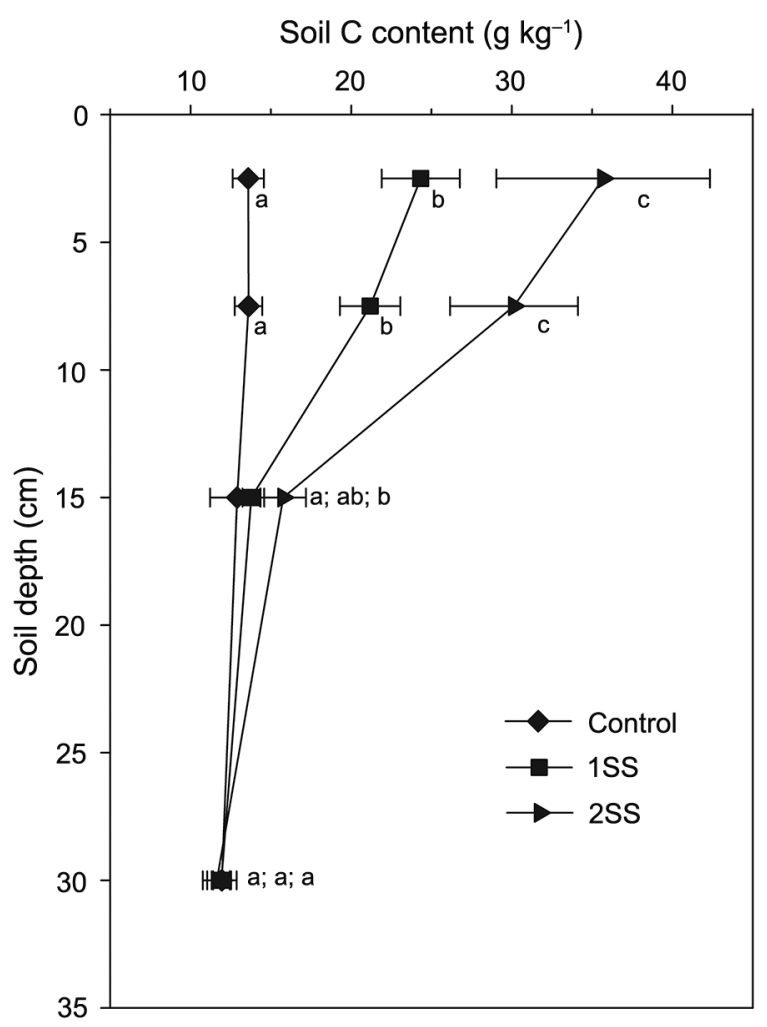

Figure 2 - A profile of carbon content distribution in soil. Different letters indicate differences between treatments $(p<0.05)$. Bars indicate standard deviation. Control represents the treatment with no SS but N mineral used instead, 1SS represents the treatment in which the recommended SS rate was applied and 2SS represents the treatment in which two times the recommend SS rate was applied. plied explained the variance in the total soil $\mathrm{C}$ content in studied soil even two years after SS application stopped. However, variations tended to decrease with soil depth (Figure 2).

Soil $\mathrm{N}$ content was highly associated with $\mathrm{C}$ content $(\mathrm{r}=0.996 ; p<0.0001)$, as it changed accordingly with it (Figure 3). In 1SS, soil $\mathrm{N}$ contents were $68 \%$ and $60 \%$ higher than in the Control series at 0-5 and 5-10 $\mathrm{cm}$ layers, respectively; whereas in 2SS treatment, soil $\mathrm{N}$ contents were $174 \%$ and $118 \%$ higher than in same layers of the Control. Below $10 \mathrm{~cm}$, soil $\mathrm{N}$ content was not statistically different across treatments.

Otherwise, soil $\mathrm{C}: \mathrm{N}$ ratios were not different across all treatments. The mean $( \pm \mathrm{SD}) \mathrm{C}: \mathrm{N}$ ratios in soil samples from each treatment and all depths were 12.29 $( \pm 0.31), 12.58( \pm 0.57)$ and $12.23( \pm 0.35)$ in the Control, 1SS and 2SS, respectively. Lower soil bulk densities at 0-5 and 5-10 cm soil depths (Table 2) were observed according to sewage sludge application $(p<0.10)$. Soil organic $\mathrm{C}$ content is positively related to soil density, since

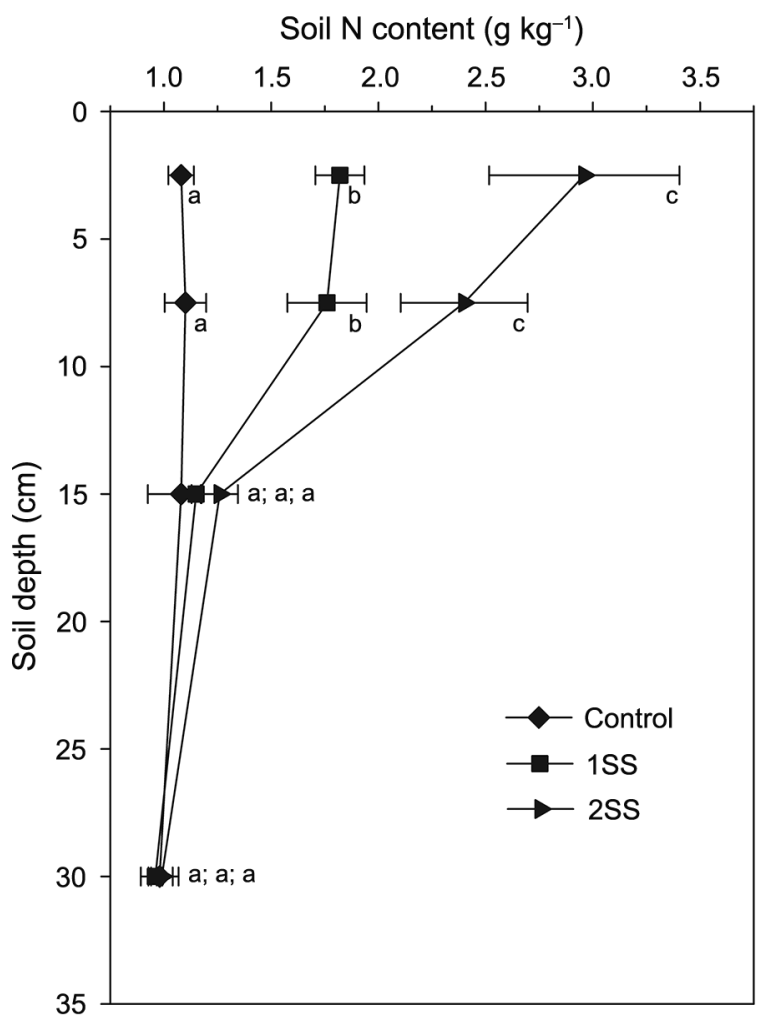

Figure 3 - A profile of nitrogen content distribution in soil. Different letters indicate differences between treatments $(p<0.05)$. Bars indicate standard deviation. Control represents the treatment with no SS but N mineral used instead, 1SS represents the treatment in which the recommended SS rate was applied and 2SS represents the treatment in which two times the recommend SS rate was applied. 
Table 2 - Soil density across soil depth after two years with no sewage sludge application in treatments *Control, 1SS and 2SS.

\begin{tabular}{|c|c|c|c|c|}
\hline \multirow{2}{*}{ Treatment } & \multicolumn{4}{|c|}{ Soil depth } \\
\hline & $0-5$ & $5-10$ & $10-20$ & $20-40$ \\
\hline & & 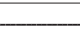 & & \\
\hline Control & ${ }^{9} 1.17^{\mathrm{b}}$ & $1.18^{\mathrm{b}}$ & $1.21^{\mathrm{a}}$ & $1.13^{\mathrm{a}}$ \\
\hline $1 S S$ & $1.08^{a}$ & $1.22^{\mathrm{b}}$ & $1.20^{\mathrm{a}}$ & $1.22^{\mathrm{a}}$ \\
\hline $2 S S$ & $1.07^{\mathrm{a}}$ & $1.07^{\mathrm{a}}$ & $1.16^{\mathrm{a}}$ & $1.25^{\mathrm{a}}$ \\
\hline$\overline{B C V}(\%)$ & 5.04 & 4.10 & 7.74 & 5.78 \\
\hline
\end{tabular}

${ }^{*}$ Control represents the treatment with no SS but N mineral used instead, 1SS represents the treatment in which the recommended SS rate was applied and 2SS represents the treatment in which two times the recommend SS rate was applied; ${ }^{9}$ Values followed by different letters indicate differences between treatments $(p<$ $0.10) ;{ }^{\beta}$ coefficient of variation.

Table 3 - Mean $\mathrm{CO}_{2}, \mathrm{CH}_{4}$ and $\mathrm{N}_{2} \mathrm{O}$ fluxes during wetter and drier periods after 2 year with no sewage sludge application in treatments *Control, $1 \mathrm{SS}$ and $2 \mathrm{SS}$.

\begin{tabular}{|c|c|c|c|}
\hline \multicolumn{4}{|c|}{ Mean fluxes in wetter period } \\
\hline Treatment & $\mathrm{CO}_{2}$ & $\mathrm{~N}_{2} \mathrm{O}$ & $\mathrm{CH}_{4}$ \\
\hline & & $-\mu \mathrm{mol} \mathrm{m}{ }^{-2}$ & \\
\hline Control & ${ }^{9} 2.37^{\mathrm{a}}$ & $0.11^{\mathrm{a}}$ & $-0.82^{a}$ \\
\hline 1SS & $3.62^{\mathrm{ab}}$ & $0.31^{\mathrm{ab}}$ & $-0.37^{a}$ \\
\hline $2 S S$ & $4.30^{\mathrm{b}}$ & $0.70^{\mathrm{b}}$ & $-0.49^{a}$ \\
\hline${ }^{B} \mathrm{CV}(\%)$ & 51.02 & 187.98 & -304.50 \\
\hline \multicolumn{4}{|c|}{ Mean fluxes in drier period } \\
\hline \multirow[t]{2}{*}{ Treatment } & $\mathrm{CO}_{2}$ & $\mathrm{~N}_{2} \mathrm{O}$ & $\mathrm{CH}_{4}$ \\
\hline & & $-\mu \mathrm{mol} \mathrm{m} \mathrm{m}^{-2}$ & \\
\hline Control & $0.21^{\mathrm{a}}$ & $0.01^{\mathrm{a}}$ & $-0.83^{a}$ \\
\hline 1SS & $0.23^{a}$ & $-0.01^{a}$ & $-0.96^{a}$ \\
\hline $2 S S$ & $0.27^{\mathrm{a}}$ & $-0.02^{a}$ & $-0.19^{a}$ \\
\hline CV (\%) & 76.84 & -1065.23 & -114.64 \\
\hline
\end{tabular}

${ }^{*}$ Control represents the treatment with no SS but $\mathrm{N}$ mineral use instead, 1SS represents the treatment in which the recommended SS rate was applied and 2SS represents the treatment in which two times the recommend SS rate was applied; ' $V$ Values followed by different letters indicate differences between treatments $(p<$ $0.05) ;{ }^{\beta}$ coefficient of variation.

it improves soil porosity (Dexter et al., 2008). These layers were also the most affected by SS addition in terms of C content (Figure 2).

Although there was no difference between $\mathrm{C}$ and $\mathrm{N}$ soil content in the deepest layer, as well as soil density, we calculated the total increases in $\mathrm{C}$ and $\mathrm{N}$ stocks attributable to changes in management practices. The mean $\mathrm{C}$ stocks were $58.8 \mathrm{Mg} \mathrm{ha}^{-1}$ in the Control, 72.5 and $83.1 \mathrm{Mg} \mathrm{ha}^{-1}$ for 1SS and 2SS, respectively. The mean $\mathrm{N}$ stocks were 4.8, 5.8, and $6.8 \mathrm{Mg} \mathrm{ha}^{-1}$ in the Control, $1 \mathrm{SS}$ and $2 \mathrm{SS}$ respectively.

Soil nitrate content $\left(\mathrm{NO}_{3}^{-}-\mathrm{N}\right)$ in the samples collected from inside each chamber after gas sampling ranged from 1.38 to $7.69 \mathrm{mg} \mathrm{kg}^{-1}$ for the Controls, 2.97$15.47 \mathrm{mg} \mathrm{kg}^{-1}$ for $1 \mathrm{SS}$ and $5.43-37.34 \mathrm{mg} \mathrm{kg}^{-1}$ for $2 \mathrm{SS}$. The mean nitrate values $\left(\mathrm{NO}_{3}^{-}-\mathrm{N}\right)$ were $3.62 \mathrm{mg} \mathrm{kg}^{-1}$ for the Control, 8.20 for 1SS and 15.59 for 2SS. Soil ammonium $\left(\mathrm{NH}_{4}{ }^{+}-\mathrm{N}\right)$ ranged from 0.04 to $4.08 \mathrm{mg} \mathrm{kg}^{-1}$ for the Control, $0.27-11.09 \mathrm{mg} \mathrm{kg}^{-1}$ for $1 \mathrm{SS}$ and $0.76-24.31 \mathrm{mg} \mathrm{kg}^{-1}$ for 2SS. Mean ammonium values $\left(\mathrm{NH}_{4}^{+}-\mathrm{N}\right)$ were 1.50 $\mathrm{mg} \mathrm{kg}^{-1}$ for the Control, 3.85 for $1 \mathrm{SS}$ and 7.39 for 2SS.

\section{Carbon and nitrogen relationship and elemental stocks}

Considering mean $\mathrm{C}$ and $\mathrm{N}$ values of the annually applied SS (Table 2), we determined the total amount of elements added to the soil after seven SS applications and compared it with respective stocks to assess the $\mathrm{C}$ and $\mathrm{N}$ dynamic. In 1SS, 19.5 and $2.0 \mathrm{Mg} \mathrm{ha}^{-1}$ of $\mathrm{C}$ and $\mathrm{N}$ were added, respectively. In 2SS, 39.1 and $4.1 \mathrm{Mg} \mathrm{ha}^{-1}$ of $\mathrm{C}$ and $\mathrm{N}$ were added, respectively. Thus, comparing these values with $\mathrm{N}$ increase we infer that $50 \%$ of the $\mathrm{N}$ applied with SS remained in the soil both in 1SS and 2SS. Disregarding differences in residues from crop production and soil incorporation over years of different treatments, $70 \%$ of $\mathrm{C}$ and $62 \%$ of $\mathrm{C}$ applied to the 2SS explains the increases in soil $\mathrm{C}$ stocks at $1 \mathrm{SS}$ and 2SS, respectively. Because the $\mathrm{C}: \mathrm{N}$ ratio settles around 12 and the fact that the same fraction of $\mathrm{N}$ from SS remained in both 1SS and 2SS suggest that $\mathrm{N}$ output is the primary variable that determines how much $\mathrm{C}$ is stored. Indeed, stoichiometry between $\mathrm{C}$, $\mathrm{N}$ and $\mathrm{P}$ is a key factor that controls the $\mathrm{C}$ storage capacity in ecosystems (Hessen et al., 2004). Despite SS application having ceased 2 years before this research was conducted, it appears that plant uptake of $\mathrm{N}$ was greater in 1SS and 2SS than in the Control (data not shown).

Another important factor that might determine the amount of $\mathrm{C}$ stored in soil is the C:N ratio of the SS. Because the parameter that limits the amount of SS applied is generally $\mathrm{N}$ content, materials with different $\mathrm{C}: \mathrm{N}$ ratios deposit the same amount of $\mathrm{N}$ and different amounts of 
C. In addition, SS with lower $\mathrm{C}: \mathrm{N}$ ratios might provide faster $\mathrm{N}$ mineralization, and thus element stocks stabilize at lower levels of $\mathrm{N}$ and $\mathrm{C}$ because the soil $\mathrm{C}: \mathrm{N}$ ratio tends to stabilize at values close to those observed in Control treatments after successive SS applications as showed by Adani and Tambone (2005), Fernandez et al. (2009), Hallin et al. (2009), Lima et al. (2009) and in this study.

We can compare the data collected in the present study with those reported by Dias et al. (2007). The study sites for both sets of experiments have similar soil texture and classification, and were managed using the same practices and subjected to the same climatic conditions because they are in neighboring counties and at the same altitude. However, Dias et al. (2007) used SS with a mean $\mathrm{C}: \mathrm{N}$ ratio of 7.3 and $\mathrm{C}$ content in soil $0-10 \mathrm{~cm}$ deep was estimated as $12 \%$ greater than in $\mathrm{N}$ fertilized soil (Control) six years after treatment. In our study, the mean C:N ratio of SS was 9.6 and $\mathrm{C}$ content in 1SS-amended soil 0-10 cm deep remained $67 \%$ higher than in $\mathrm{N}$ fertilized soil (Control) even after two years with no SS application. Adani and Tambone (2005) did not find any changes in $\mathrm{C}$ soil content $(0-25 \mathrm{~cm}$ depth) between SS and Control treatments after 10 annual SS applications; thus, the $\mathrm{C}: \mathrm{N}$ ratio was equal to 5.3 . In this context, we attribute to the $\mathrm{C}: \mathrm{N}$ ratio the high $\mathrm{C}$ storage achieved in this work, which reflects characteristics of recalcitrance. In this case, $\mathrm{C}$ accumulation overcomes those observed in Ferralsols after long term conversion from conventional tillage to no-tillage in subtropical climates in Brazil (Boddey et al., 2010).

Lower C:N ratios are found in less stable SS generated by the activated sludge process (Beecher, 2008). The activated sludge process is highly efficient in smaller areas and it is used in metropolitan regions abroad (Boon, 2003). Conversely, SS with a higher C:N ratio is produced by slower stabilization processes in water reclamation stations as the one used in this study. This slower process uses an aerated lagoon followed by decantation. In a region with the largest waste reclamation treatment plants in the world, SS is quickly generated by fast processing. However, it becomes biologically stabilized remaining for a relatively extended time period in patios (Tian et al., 2009). Thereafter, the soil supported high $\mathrm{C}$ storage after consecutive SS applications (Tian et al., 2009). Thus, an alternative for obtaining more stabilized SS could be implemented with secondary treatments.

\section{$\mathrm{CO}_{2}$}

We found significant correlations between $\mathrm{CO}_{2}$ fluxes and water availability ( $\mathrm{p}$-values in Control $<1 \mathrm{SS}<$ 2SS), temperature (p-values $2 \mathrm{SS}<1 \mathrm{SS}<$ Control) and both variables together $(p<0.0001)$. In 2SS alone, an exponential adjustment was included in the regression equation (Figure 4). For $\mathrm{N}_{2} \mathrm{O}$ and $\mathrm{CH}_{4}$, we found no significant correlations between these measurements or any other variables, including mineral $\mathrm{N}$ or WFPS. In addition, by curve inclination (Figure 4) and probability levels obtained from regressions, we found that after SS treatment, $\mathrm{CO}_{2}$ flux from soil is more dependent on temperature than the Control. The angular coefficients for the Control, 1SS and 2SS were 0.105, 0.3276 and 0.404 $\mu \mathrm{mol} \mathrm{CO}_{2} \mathrm{~m}^{-2} \mathrm{~s}^{-1}$ per ${ }^{\circ} \mathrm{C}$ change in temperature, respectively.

Temperature dependence of organic matter mineralization in soils is a function of organic matter availability (Davidson and Janssens, 2006). The more organic matter became available (i.e. as result of moisture status, less aggregation or adsorption capacity), the more intense the effects of temperature on $\mathrm{C}$ mineralization. On the other hand, Davidson and Janssens (2006) also highlighted the role of organic matter quality in temperature sensitivity. Although the added organic matter might in part be more available in the soil, it also presented intrinsic characteristics which led to $\mathrm{C}$ sequestration. Moreover, since $\mathrm{N}$ has been indicated as a primary parameter for $\mathrm{C}$ sequestration by regulating organic matter turnover, the higher $\mathrm{C}$ mineralization might be balanced by increases in crop residues' deposition (Kirschbaum, 2006), which corroborates the retention of the great amount of $\mathrm{C}$ observed. Although this feedback may contribute to retention of $\mathrm{C}$ in the system, it is not well established and is a gap in the precursor models developed to predict soil organic matter dynamics (Kirschbaum, 2006).

The simulations using these models have pointed to $\mathrm{C}$ accumulation as a result of global warming in tropical ecosystems due to this gap concerning $\mathrm{N}$ turnover (Kirschbaum, 2006). Recently, modules considering N use efficiency have been proposed to improve the models' performance (Mooshammer et al., 2014; Wieder et al., 2013) but it still needs to be validated under different scenarios. Considering the lack of response of maize respiration to temperature and the same autotrophic respiration rates in all treatments, we were able to estimate the effects of temperature on $\mathrm{C}$ release from the soil. According to our observations, C mineralization increased $0.2226 \mu \mathrm{mol} \mathrm{m}{ }^{-2} \mathrm{~s}^{-1}$ per ${ }^{\circ} \mathrm{C}$ from the Control to $1 \mathrm{SS}$. Using stoichiometry (C:N=12:1; $\mathrm{m}: \mathrm{m})$, it is equivalent to $0.0159 \mu \mathrm{mol}$ of $\mathrm{N} \mathrm{m}^{-2} \mathrm{~s}^{-1}$. Following the same estimates, each $1^{\circ} \mathrm{C}$ stimulates the mineralization of $840 \mathrm{~kg}$ of $\mathrm{C}$ and $70 \mathrm{~kg}$ of $\mathrm{N} \mathrm{ha}^{-1} \mathrm{yr}^{-1}$ in $1 \mathrm{SS}$ when compared with the Control. When comparing the Control and 2SS, each $1{ }^{\circ} \mathrm{C}$ stimulates the mineralization of $1131 \mathrm{~kg}$ of $\mathrm{C}$ and $94 \mathrm{~kg}$ of $\mathrm{N} \mathrm{ha}^{-1} \mathrm{yr}^{-1}$. Since the C:N ratio tends to remain stable, the fraction of this $\mathrm{N}$ lost by leaching, denitrification or exported as grains was proportional to the $\mathrm{C}$ decay in the SS-amended soil as a result of increases in soil temperature. For maize, Vicca et al. (2010) verified that $\mathrm{CO}_{2}$ emissions from plant respiration under water-sufficient conditions do not show sensitivity to temperature, unlike $\mathrm{CO}_{2}$ emissions from organic matter in soil. However, other factors, such as water content, might also regulate $\mathrm{CO}_{2}$ flux, which could act as a cofactor that regulates $\mathrm{CO}_{2}$ flux from soils (Davidson et al., 1998; Molen et al., 2011). We obtained 

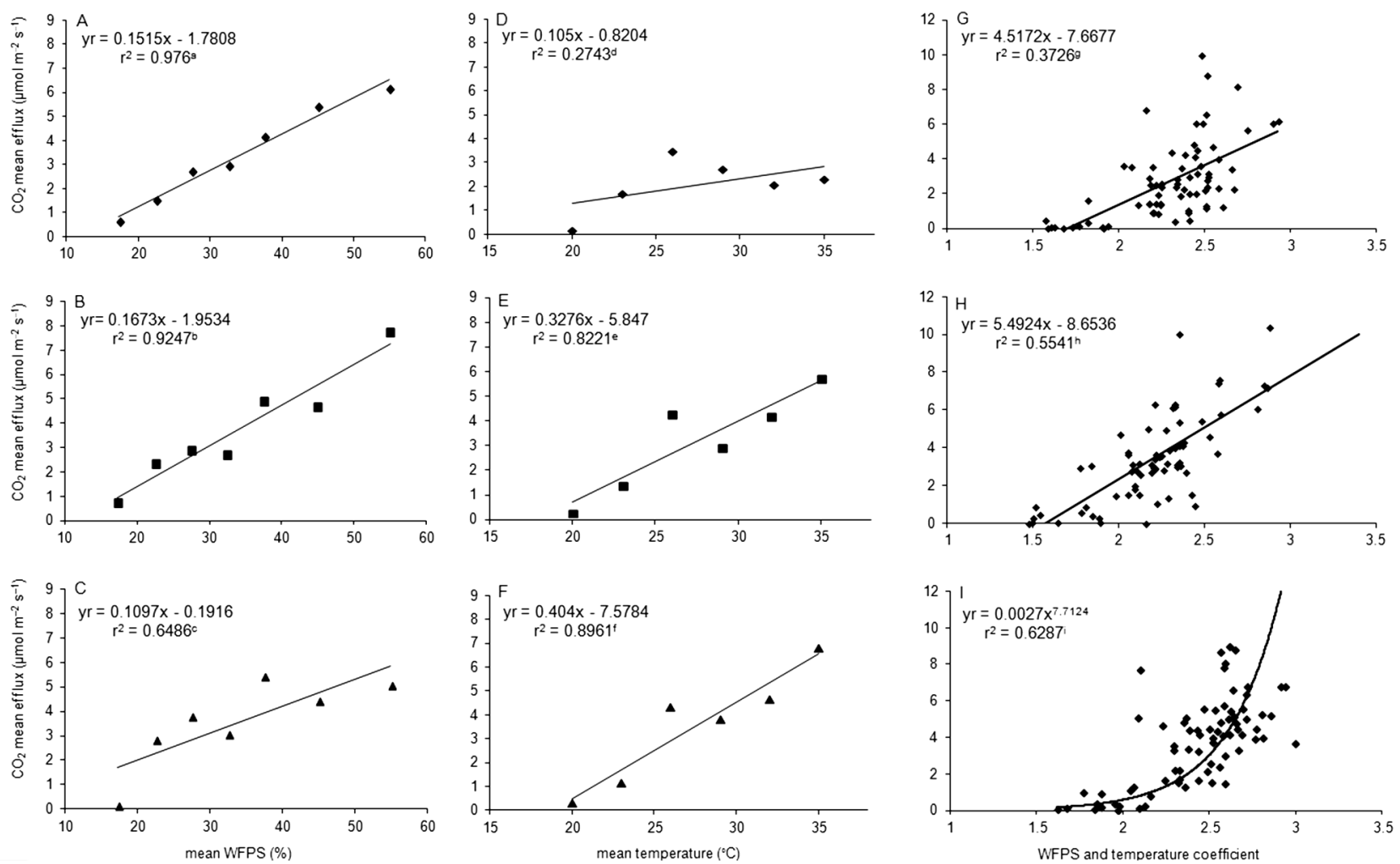

Figure 4 - Relationships between $\mathrm{CO}_{2}$ flux, water-filled pore space $(A, B$ and $C$ ), temperature $(D, E$ and $F$ ) and multiple regression with both variables (G, H and I; see statistical methods) in the Control (A, D and G), 1SS (B, E and H) and 2SS (C, E and I) treatments. Control represents the treatment with no SS but N mineral used instead, 1SS represents the treatment in which the recommended SS rate was applied and 2SS represents the treatment in which two times the recommend SS rate was applied. ${ }^{A} p<0.0001 ;{ }^{B} p=0.0005 ;{ }^{C} p=0.02882 ;{ }^{D} p=0.28626$; ${ }^{\mathrm{E}} p=0.01265 ;{ }^{\mathrm{F}} p=0.0042 ;{ }^{\mathrm{G}} p<0.0001 ;{ }^{H} p<0.0001 ;{ }^{\prime} p<0.0001$. In "l", an exponential regression adjustment was applied.

high significance levels for multiple regressions between $\mathrm{CO}_{2}$ flux and temperature associated with WFPS for all treatments, but in 2SS, an exponential adjustment was included in the regression equation.

Because heterotrophic and autotrophic metabolisms are significant sources of $\mathrm{CO}_{2}$ from soil and the ratio between them is unknown (Kuzyakov, 2006), and we did not use plant productivity values, we were unable to predict the rate of $\mathrm{C}$ decay. However, emissions from 1SS and 2SS were $50 \%$ and $78 \%$ greater than from the Control, respectively (Table 4). Hence, we can use the same concepts as described for the effects of temperature to estimate the $\mathrm{C}$ lost related to the residual effects. In terms of $\mathrm{N}$, these values represent 202 and $315 \mathrm{~kg} \mathrm{ha}^{-1}$ for $1 \mathrm{SS}$ and $2 \mathrm{SS}$, respectively. The $\mathrm{N}$ exported from the system or lost by biogeochemical processes were proportional to the $\mathrm{C}$ lost. When we observed changes in soil management practices and $C$ sequestration, it is assumed that this $\mathrm{C}$ could be returned to the atmosphere if the practices are reversed. This will follow as long as the system gets close to a new equilibrium in terms of $\mathrm{C}$ balance, which occurs in long term scales (Wutzler and Reichstein, 2007). As an example, Urzedo et al. (2013)
Table 4 - Weighting ${ }^{\delta}$ seasonal fluxes of $\mathrm{CO}_{2}, \mathrm{CH}_{4}$ and $\mathrm{N}_{2} \mathrm{O}$ and estimated ${ }^{*}$ emissions in treatments ${ }^{*}$ Control, 1SS and 2SS.

\begin{tabular}{lccc}
\hline Treatment & \multicolumn{3}{c}{$\mathrm{CO}_{2}$} \\
\hline \multirow{2}{*}{ Control } & $\mu \mathrm{mol} \mathrm{m}^{-2} \mathrm{~s}^{-1}$ & $\mathrm{Mg} \mathrm{C} \mathrm{ha}^{-1} \mathrm{yr}^{-1}$ & $\mathrm{Mg} \mathrm{eqCO}_{2} \mathrm{ha}^{-1} \mathrm{yr}^{-1}$ \\
1SS & 1.29 & 4.88 & 17.90 \\
2SS & 1.93 & 7.30 & 26.78 \\
\hline Treatment & 2.29 & 8.67 & 31.78 \\
\hline \multicolumn{4}{c}{$\mathrm{N}_{2} \mathrm{O}$} \\
Control & $\mu \mathrm{mol} \mathrm{m}^{-2} \mathrm{~h}^{-1}$ & $\mathrm{~kg} \mathrm{~N} \mathrm{ha}^{-1} \mathrm{yr}^{-1}$ & $\mathrm{~kg} \mathrm{eqCO}_{2} \mathrm{ha}^{-1} \mathrm{yr}^{-1}$ \\
1SS & 0.06 & 0.15 & 68.54 \\
2SS & 0.15 & 0.37 & 172.84 \\
Treatment & 0.34 & 0.83 & 390.28 \\
\hline \multicolumn{4}{c}{} \\
Control & $\mu \mathrm{mol} \mathrm{m} \mathrm{h} \mathrm{h}^{-1}$ & $\mathrm{~kg} \mathrm{C} \mathrm{ha}_{4}^{-1} \mathrm{yr}^{-1}$ & $\mathrm{~kg} \mathrm{eqCO}_{2} \mathrm{ha}^{-1} \mathrm{yr}^{-1}$ \\
1SS & -0.82 & -0.86 & -28.75 \\
2SS & -0.66 & -0.69 & -23.00 \\
\hline
\end{tabular}

हWeighting accounts for wetter and drier seasonal fluxes; ${ }^{* *} \mathrm{CO}_{2}$ equivalents according to IPCC (2007), where $\mathrm{CO}_{2}, \mathrm{CH}_{4}$ and $\mathrm{N}_{2} \mathrm{O}$ GWPs are 1,25 and 298, respectively; * ${ }^{*}$ Control represents the treatment with no SS but N mineral use instead, 1SS represents the treatment in which the recommended SS rate was applied and 2SS represents the treatment in which two times the recommend SS rate was applied. 
observed that in the first growing season after SS application less than $1 \%$ of the added $\mathrm{C}$ was released as $\mathrm{CO}_{2}$ in a forestry experiment.

\section{$\mathrm{N}_{2} \mathrm{O}$ and $\mathrm{CH}_{4}$}

Because the GWP of $\mathrm{N}_{2} \mathrm{O}$ is 298 times greater than $\mathrm{CO}_{2}$ (IPCC, 2007), emissions of this compound might reduce agriculture sustainability or compromise benefits arising from management changes. While IPCC (2006) recommends using a default value of $1 \%$ for the applied $\mathrm{N}$ emitted as $\mathrm{N}_{2} \mathrm{O}$, Crutzen et al. (2008) suggests that this amount ranges from $3 \%$ to $5 \%$. Considering this range, ethanol from maize crops does not mitigate global warming. Briefly, Crutzen et al. (2008) obtained this range correlating increases in fertilizer use and $\mathrm{N}_{2} \mathrm{O}$ atmospheric concentrations. Thus, their estimate includes indirect emissions from agricultural $\mathrm{N}$ lost to the environment as those described by Galloway et al. (2004).

After SS use, indirect emissions would come from residual effects, in which $\mathrm{C}$ and $\mathrm{N}$ are still abundantly available to stimulate $\mathrm{N}_{2} \mathrm{O}$ emission. The residual SS effect increased $\mathrm{N}_{2} \mathrm{O}$ flux from soil, but our results in 1SS are similar to those found in non-fertilized moist tropical forests, as shown by Konda et al. (2010). In this report, the authors obtained a mean $\mathrm{N}_{2} \mathrm{O}$ flux of $0.39 \mu \mathrm{mol} \mathrm{m} \mathrm{m}^{-2}$ $\mathrm{h}^{-1}$ in the wet season. Souza-Neto et al. (2011) reported annual means ranging from 0.32 to $0.36 \mu \mathrm{mol} \mathrm{m} \mathrm{m}^{-2} \mathrm{~h}^{-1}$ in the Brazilian Atlantic forest. In 1SS, we found a mean flux of $0.31 \mu \mathrm{mol} \mathrm{m} \mathrm{m}^{-2} \mathrm{~h}^{-1}$ in the wetter season (Table 3).

No correlations between $\mathrm{N}_{2} \mathrm{O}$ flux and environmental variables were verified in any of the treatments. This might be explained by simultaneous processes in volving production or consumption of $\mathrm{N}_{2} \mathrm{O}$, like nitrification and denitrification, as demonstrated by Farquharson and Baldock (2008).

Between GHG emissions related to agriculture and land use changes, only $\mathrm{CH}_{4}$ atmospheric concentration was decreased to levels comparable to those measured in the 1990's (Bousquet et al., 2006). Well-drained soils usually act as a sink for $\mathrm{CH}_{4}$ (Conrad, 2009; Holmes et al., 1999), which was confirmed regardless of season either in the presence or absence of SS. For each treatment, no differences were observed between treatments or seasons, although gradual $\mathrm{CH}_{4}$ uptake inhibition had been verified according to the SS rate.

\section{Conclusions}

Carbon dioxide flux from soil under the residual effect of SS shows high temperature dependence, indicating that its organic matter is more available than in SS non-amended soil. However, large stores of carbon following historical SS application demonstrate that its use could be a method for carbon sequestration, even under tropical conditions. Sewage sludge properties (e.g. C:N ratio) contribute to the determination of carbon storage capacity. Although the residual effects of sewage sludge caused increases in $\mathrm{N}_{2} \mathrm{O}$ flux, after recommended rates the fluxes were similar to those found in moist forest ecosystems and might not be considered an important indirect impact of SS residual effects.

\section{Acknowledgements}

The authors would like to acknowledge the invaluable help of Dr. Fábio R. P. Rocha for optimization of the flow inject analysis methods. We also thank Eráclito Sousa Neto, Fabiana Fracassi, Daniel L. G. Monaro and Renan C. Fantini for contributions in the laboratory and field.

\section{References}

Adani, F; Tambone, F. 2005. Long-term effect of sewage sludge application on soil humic acids. Chemosphere 60: 1214-1221.

Alvares, C.A.; Stape, J.L.; Sentelhas, P.C.; Gonçalves, J.L.M.; Sparovek, G. 2013. Koppen's climate classification map for Brazil. Meteorologische Zeitschrift 22: 711-728.

Beecher, N. 2008. Overview. In: Blanc, R.J.; Matthews, P.; Richard, R.P., eds. Global Atlas of Excreta, Wastewater Sludge, and Biosolids Management: Moving Forward the Sustainable and Welcome Uses of a Global Resource. UN-HABITAT, New Brunswick, Canada.

Boddey, R.M.; Jantalia, C.P.; Conceicao, P.C.; Zanatta, J.A.; Bayer, C.; Mielniczuk, J.; Dieckow, J.; Santos, H.P.; Denardin, J.E.; Aita, C.; Giacomini, S.J.; Alves, B.J.R.; Urquiaga, S. 2010. Carbon accumulation at depth in Ferralsols under zero-till subtropical agriculture. Global Change Biology 16: 784-795.

Bonanomi, G.; Antignani, V.; Capodilupo, M.; Scala, F. 2010. Identifying the characteristics of organic soil amendments that suppress soilborne plant diseases. Soil Biology \& Biochemistry 42: $136-144$

Boon, A.G. 2003. Sequencing batch reactors: a review. Journal of the Chartered Institution of Water and Environmental Management 17: 68-73.

Bousquet, P.; Ciais, P.; Miller, J.B.; Dlugokencky, E.J.; Hauglustaine, D.A.; Prigent, C.; Werf, G.R. van der; Peylin, P.; Brunke, E.G.; Carouge, C.; Langenfelds, R.L.; Lathiere, J.; Papa, F.; Ramonet, M.; Schmidt, M.; Steele, L.P.; Tyler, S.C.; White, J. 2006. Contribution of anthropogenic and natural sources to atmospheric methane variability. Nature 443: 439-443.

Carmo, J.B.; Keller, M.; Dias, J.D.; de Camargo, P.B.; Crill, P. 2006. A source of methane from upland forests in the Brazilian Amazon. Geophysical Research Letters 33: L04809.

Childers, D.L.; Corman, J.; Edwards, M.; Elser, J.J. 2011. Sustainability challenges of phosphorus and food: solutions from closing the human phosphorus cycle. Bioscience 61: 117124.

Conselho Nacional de Meio Ambiente [CONAMA]. 2006. Management of wastes and hazardous materials: use $=$ Gestão de resíduos e produtos perigosos: uso. Diário Oficial da União, Brasília, DF, Brazil. Available at: http://www.mma.gov.br/port/ conama/legiabre.cfm?codlegi $=506$ [Accessed in Mar 13, 2009].

Conrad, R. 2009. The global methane cycle: recent advances in understanding the microbial processes involved. Environmental Microbiology Reports 1: 285-292. 
Crutzen, P.; Mosier, A.; Smith, K.; Winiwarter, W. 2008. N2O release from agro-biofuel production negates global warming reduction by replacing fossil fuels. Atmospheric Chemistry and Physics 389-395.

Davidson, E.A.; Belk, E.; Boone, R.D. 1998. Soil water content and temperature as independent or confounded factors controlling soil respiration in a temperate mixed hardwood forest. Global Change Biology 4: 217-227.

Davidson, E.A.; Keller, M.; Erickson, H.E.; Verchot, L.V.; Veldkamp, E. 2000. Testing a conceptual model of soil emissions of nitrous and nitric oxides. Bioscience 50: 667-680.

Davidson, E.A.; Savage, K.; Verchot, L.V.; Navarro, R. 2002. Minimizing artifacts and biases in chamber-based measurements of soil respiration. Agricultural and Forest Meteorology 113: 21-37.

Davidson, E.A.; Janssens, I.A. 2006. Temperature sensitivity of soil carbon decomposition and feedbacks to climate change. Nature 440: 165-173.

Dexter, A.R.; Richard, G.; Arrouays, D.; Czyz, E.A.; Jolivet, C.; Duval, O. 2008. Complexed organic matter controls soil physical properties. Geoderma 144: 620-627.

Dias, B.D.; Silva, C.A.; Soares, E.M.B.; Bettiol, W. 2007. Organic carbon stock and quantification of humic substances of an oxisol under continuous sewage sludge application. Revista Brasileira de Ciencia do Solo 31: 701-711.

Elser, J.J. 2012. Phosphorus: a limiting nutrient for humanity? Current Opinion in Biotechnology 23: 833-838.

Food and Agriculture Organization [FAO]. 1998. World Reference Base for Soil Resources. FAO, Rome, Italy.

Farquharson, R.; Baldock, J. 2008. Concepts in modelling N2O emissions from land use. Plant and Soil 309: 147-167.

Fernandez, J.M.; Hernandez, D.; Plaza, C.; Polo, A. 2007. Organic matter in degraded agricultural soils amended with composted and thermally-dried sewage sludges. Science of the Total Environment 378: 75-80.

Fernandez, J.M.; Plaza, C.; Garcia-Gil, J.C.; Polo, A. 2009. Biochemical properties and barley yield in a semiarid Mediterranean soil amended with two kinds of sewage sludge. Applied Soil Ecology 42: 18-24.

Galdos, M.V.; De Maria, I.C.; Camargo, O.A. 2004. Soil chemical properties and corn production in a sewage sludge-amended soil. Revista Brasileira de Ciência do Solo 28: 569-577.

Galdos, M.V.; De Maria, I.C.; de Camargo, O.A.; Dechen, S.C.F. 2009. Sewage sludge application on cultivated soils: effects on runoff and trace metal load. Scientia Agricola 66: 368-376.

Galloway, J.N.; Dentener, F.J.; Capone, D.G.; Boyer, E.W.; Howarth, R.W.; Seitzinger, S.P.; Asner, G.P.; Cleveland, C.C.; Green, P.A.; Holland, E.A.; Karl, D.M.; Michaels, A.F.; Porter, J.H.; Townsend, A.R.; Vorosmarty, C.J. 2004. Nitrogen cycles: past, present, and future. Biogeochemistry 70: 153-226.

Garcia-Orenes, F.; Guerrero, C.; Mataix-Solera, J.; NavarroPedreno, J.; Gomez, I.; Mataix-Beneyto, J. 2005. Factors controlling the aggregate stability and bulk density in two different degraded soils amended with biosolids. Soil \& Tillage Research 82: 65-76.

Gerba, C.P.; Smith, J.E. 2005. Sources of pathogenic microorganisms and their fate during land application of wastes. Journal of Environmental Quality 34: 42-48.
Hallin, S.; Jones, C.M.; Schloter, M.; Philippot, L. 2009. Relationship between $\mathrm{N}$-cycling communities and ecosystem functioning in a 50-year-old fertilization experiment. ISME Journal 3: 597-605.

Hessen, D.O.; Agren, G.I.; Anderson, T.R.; Elser, J.J.; De Ruiter, P.C. 2004. Carbon, sequestration in ecosystems: the role of stoichiometry. Ecology 85: 1179-1192.

Holmes, A.J.; Roslev, P.; McDonald, I.R.; Iversen, N.; Henriksen, K.; Murrell, J.C. 1999. Characterization of methanotrophic bacterial populations in soils showing atmospheric methane uptake. Applied and Environmental Microbiology 65: 3312-3318.

International Panel on Climate Change [IPCC]. 2007. Climate Change 2007. In: Metz, B.; Davidson, O.R.; Bosch, P.R.; Dave, R.; Meyer, L.A., eds. The Physical Science Basis, Contribution of Working Group I, II and III to the Fourth Assessment Report of the IPCC. Cambridge University Press, Cambridge, UK.

International Panel on Climate Change [IPCC]. 2006. Guidelines for National Greenhouse Gas Inventories. IGES, Tokyo, Japan.

International Organization for Standarlization [ISO]. 1998. ISO 11277 - Determination of Particlesize Distribution in Mineral Soil Material - Method by Sieving and Sedimentation. Geneva, Switzerland.

Kamphake, L.J.; Hannah, S.A.; Cohen, J.M. 1967. Automated analysis for nitrate by hydrazine reduction. Water Research 1 : 205-216.

Kirschbaum, M.U.F. 2006. The temperature dependence of organic-matter decomposition - still a topic of debate. Soil Biology \& Biochemistry 38: 2510-2518.

Konda, R.; Ohta, S.; Ishizuka, S.; Heriyanto, J.; Wicaksono, A. 2010. Seasonal changes in the spatial structures of N2O, CO2, and $\mathrm{CH} 4$ fluxes from Acacia mangium plantation soils in Indonesia. Soil Biology \& Biochemistry 42: 1512-1522.

Krom, M.D. 1980. Spectrophotometric determination of ammonia: a study of a modified berthelot reaction using salicylate and dichloroisocyanurate. Analyst 105: 305-316.

Kuzyakov, Y. 2006. Sources of CO2 efflux from soil and review of partitioning methods. Soil Biology \& Biochemistry 38: 425-448.

Lal, R. 2008. Carbon sequestration. Philosophical Transactions of the Royal Society B-Biological Sciences 363: 815-830.

Le Mer, J.; Roger, P. 2001. Production, oxidation, emission and consumption of methane by soils: a review. European Journal of Soil Biology 37: 25-50.

Lima, D.L.D.; Santos, S.M.; Scherer, H.W.; Schneider, R.J.; Duarte, A.C.; Santos, E.B.H.; Esteves, V.I. 2009. Effects of organic and inorganic amendments on soil organic matter properties. Geoderma 150: 38-45.

Molen, M.K. van der; Dolman, A.J.; Ciais, P.; Eglin, T.; Gobron, N.; Law, B.E.; Meir, P.; Peters, W.; Phillips, O.L.; Reichstein, M.; Chen, T.; Dekker, S.C.; Doubkova, M.; Friedl, M.A.; Jung, M.; van den Hurk, B.; de Jeu, R.A.M.; Kruijt, B.; Ohta, T.; Rebel, K.T.; Plummer, S.; Seneviratne, S.I.; Sitch, S.; Teuling, A.J.; van der Werf, G.R.; Wang, G. 2011. Drought and ecosystem carbon cycling. Agricultural and Forest Meteorology 151: 765-773.

Mooshammer, M.; Wanek, W.; Haemmerle, I.; Fuchslueger, L.; Hofhansl, F.; Knoltsch, A.; Schnecker, J.; Takriti, M.; Watzka, M.; Wild, B.; Keiblinger, K.M.; Zechmeister-Boltenstern, S.; Richter, A. 2014. Adjustment of microbial nitrogen use efficiency to carbon: nitrogen imbalances regulates soil nitrogen cycling. Nature Communications 5: 3694. 
Navarro, I.; Jimenez, B.; Cifuentes, E.; Lucario, S. 2009. Application of Helminth ova infection dose curve to estimate the risks associated with biosolid application on soil. Journal of Water and Health 7: 31-44.

Nogueira, T.A.R.; Melo, W.J.; Fonseca, I.M.; Marcussi, S.A.; Melo, G.M.P.; Marques, M.Q. 2010. Fractionation of $\mathrm{Zn}, \mathrm{Cd}$ and $\mathrm{Pb}$ in a tropical soil after nine-year sewage sludge applications. Pedosphere 20: 545-556.

Raij, B. van; Cantarella, H.; Quaggio, J.A.; Furlani, A.M.C. 1997. Recommendations for fertilization and liming in the State of São Paulo = Recomendações de adubação e calagem para o Estado de São Paulo. Instituto Agronômico, Campinas, SP, Brazil (in Portuguese).

Sey, B.K.; Manceur, A.M.; Whalen, J.K.; Gregorich, E.G.; Rochette, P. 2008. Small-scale heterogeneity in carbon dioxide, nitrous oxide and methane production from aggregates of a cultivated sandy-loam soil. Soil Biology \& Biochemistry 40: 2468-2473.

Singh, R.P.; Agrawal, M. 2008. Potential benefits and risks of land application of sewage sludge. Waste Management 28: 347-358.

Smith, S.R. 2009. Organic contaminants in sewage sludge (biosolids) and their significance for agricultural recycling. Philosophical Transactions of the Royal Society A- Mathematical Physical and Engineering Sciences 367: 4005-4041.

Souza-Neto, E.; Carmo, J.B.; Keller, M.; Martins, S.C.; Alves, L.F.; Vieira, S.A.; Piccolo, M.C.; Camargo, P.; Couto, H.T.Z.; Joly, C.A.; Martinelli, L.A. 2011. Soil-atmosphere exchange of nitrous oxide, methane and carbon dioxide in a gradient of elevation in the coastal Brazilian Atlantic forest. Biogeosciences 8: 733-742.
Stein, L.Y. 2011. Surveying N2O-producing pathways in bacteria. Methods in Enzymology. 486: 131-152.

Tian, G.; Granato, T.C.; Cox, A.E.; Pietz, R.I.; Carlson, C.R.; Abedin, Z. 2009. Soil carbon sequestration resulting from longterm application of biosolids for land reclamation. Journal of Environmental Quality 38: 61-74.

Urzedo, D.I.; Franco, M.P.; Pitombo, L.M.; Carmo, J.B. 2013. Effects of organic and inorganic fertilizers on greenhouse gas (GHG) emissions in tropical forestry. Forest Ecology and Management 310: 37-44.

Vicca, S.; Janssens, I.A.; Wong, S.C.; Cernusak, L.A.; Farquhar, G.D. 2010. Zea mays rhizosphere respiration, but not soil organic matter decomposition was stable across a temperature gradient. Soil Biology \& Biochemistry 42: 2030-2033.

Wang, R. 2011. Environmental and resource sustainability of Chinese cities: a review of issues, policies, practices and effects. Natural Resources Forum 35: 112-121.

Ward, B. B. 2008. Nitrification. p. 2511-2518. In: Jorgensen, S.E.; Faith, B.D., eds. Encyclopedia of Ecology. Elsevier, Oxford, UK.

Wieder, W.R.; Bonan, G.B.; Allison, S.D. 2013. Global soil carbon projections are improved by modelling microbial processes. Nature Climate Change 3: 909-912.

Wilson, D.C. 2007. Development drivers for waste management. Waste Management \& Research 25: 198-207.

Wutzler, T.; Reichstein, M. 2007. Soils apart from equilibrium: consequences for soil carbon balance modelling. Biogeosciences 4: $125-136$. 